KEYNOTE SPEECH

\title{
False Hope and Empty Promises from a Priest-King in the East: How Environment and Communication Shape Belief
}

\author{
Joaquim Baeta \\ Researcher (Portugal)
}

\begin{abstract}
As the $12^{\text {th }}$ century entered its midpoint, unease permeated through Christendom. In 1144, the County of Edessa had fallen to Zengi, the atabeg of Mosul and Aleppo, signalling that all was not well in the Holy Land. News of the fall of Edessa quickly travelled westward, with the Catholic Pope, Eugenius III, issuing a papal bull calling for a Second Crusade in December of the next year. Nevertheless, for the Edessa's fellow Crusader states, the restlessness of being surrounded by the Islamic had turned to alarm. Help was gravely needed. Then came word of aid from an unlikely place: the East itself. Rumours had swirled of a Christian monarch in the East, but actual proof of his existence was scant, based mainly on fantastical tales of the Orient. That changed in December of 1145 , with a conversation between Bishops Otto of Freising and Hugh of Jabala. Hugh told Otto of a Nestorian Christian priest-king "beyond Persia and Armenia", who had "warred upon the so--called Samiards, the brother kings of the Medes and Persians." More critically, Hugh reported that this priest-king had "moved his army to aid the church of Jerusalem" but was unable to cross the Tigris and returned home. Such was the legend of Prester John, the ruler of an eastern Christian kingdom that offered hope and little else to a Christian West that would steadily lose its grip on the Holy Land. Why did Prester John never come to the aid of the Crusader states? The story of this priestking, his supposed interactions with western Christendom and ultimate failure to deliver on his promises, reveals how the environment we inhabit and the methods we use to communicate shape our beliefs and values, and that as our environments and communication methods change, so do these beliefs and values.
\end{abstract}

Keywords: Belief, Christianity, Islam, Prester John, Religion 